\title{
The effect of moderately increased intakes of complex carbohydrates (cereals, vegetables and fruit) for 12 weeks on iron and zinc metabolism
}

\author{
BY PAMELA M. MASON AND PATRICIA A. JUDD \\ King's College London, Kensington (Queen Elizabeth) Campus, Campden Hill Road, \\ London $W 87 \mathrm{AH}$ \\ AND SUSAN J. FAIRWEATHER-TAIT* AND JOHN EAGLES \\ AFRC Institute of Food Research, Colney Lane, Norwich NR4 7UA, Norfolk \\ AND MARGARET J. MINSKI \\ Imperial College Reactor Centre, Silwood Park, Ascot, Berks SL5 7 PY
}

(Received 4 September 1989 - Accepted 13 December 1989)

\begin{abstract}
Fifteen adult women were given diets in which the intake of complex carbohydrates was increased from 20 to $30 \mathrm{~g}$ over a 12 week period. Metabolic balances were carried out, iron and zinc absorption tests performed using stable isotopes, and $\mathrm{Fe}$ and $\mathrm{Zn}$ status monitored. Although effects on bowel function were observed, the changed diet had no influence on any of the previously described variables. It was concluded that a moderate increase in cereals, fruit and vegetables did not have an adverse effect on $\mathrm{Fe}$ or $\mathrm{Zn}$ nutrition.
\end{abstract}

Complex carbohydrates: Iron: Mineral availability: Zinc

Recent dietary recommendations have suggested that intakes of complex carbohydrates (dietary fibre) be increased in the UK diet from 20 to $30 \mathrm{~g} / \mathrm{d}$ (National Advisory Committee on Nutrition Education (NACNE), 1983) or that the reduction in energy intake resulting from the reduced fat intake proposed by the Committee on Medical Aspects of Health (COMA) (Department of Health and Social Security, 1984) should be compensated for by increased amounts of fibre-rich carbohydrates. A recent report from the Federation of American Societies for Experimental Biology (Pilch, 1987) has recommended an upper limit of $35 \mathrm{~g} / \mathrm{d}$. Health may be improved and disease reduced if this objective is achieved but there is some concern that mineral availability may be impaired by a diet high in complex carbohydrates.

There is some evidence that complex carbohydrates reduce the absorption of certain minerals, but a recent review (Walker, 1987) shows that the results from human studies are conflicting. Problems arise due to the different levels of complex carbohydrates fed, some of the intakes bearing little relation to the human dietary situation (Rattan et al. 1981). The use of different sources (bran, pectin, cellulose and hemicellulose) and different foods (cereals, fruits and vegetables) also makes overall interpretation of the studies difficult. Concurrent changes in mineral intake associated with consumption of foods high in complex carbohydrates add to the confusion. Furthermore, many also contain phytate and it is difficult to separate the effects of these two components, both having the ability to bind 
minerals in vitro. Recent experimental evidence, however, points to phytate rather than complex carbohydrates as a major determinant of mineral availability (Andersson et al. 1983; Hallberg et al. 1987).

The situation is further complicated because different methods of analysis have been used to measure the intake of complex carbohydrates (Southgate \& Englyst, 1985), and different techniques employed to assess mineral absorption. The metabolic balance is often used in human studies, but more recently stable isotopes have been employed as more accurate and versatile methods of studying mineral absorption (Fairweather-Tait \& Minski, 1986).

Most of the studies conducted so far have been of short duration (10-30 d) and whilst the majority have attempted dietary control, some have relied on specific fibre supplements added to self-selected diets. Long-term studies are difficult to control but there is some evidence that adaptation to changes in both complex carbohydrates (Walker et al. 1948) and nutrient intake (Hegsted et al. 1952; Malm, 1958) can occur. For example, vegetarians showed no evidence of depressed iron and zinc status despite high intakes of complex carbohydrates (Anderson et al. 1981), and epidemiological studies indicate that populations habitually consuming diets high in complex carbohydrates do not have poor mineral status (Walker, 1987).

Therefore, even if a diet high in complex carbohydrates reduces mineral absorption in the short term, the body may respond in the longer term by gradually increasing the efficiency of absorption. This may depend on changes in mucosal transport, including the site of maximal absorption, or alterations in microbial metabolism whereby the minerals are released from their bound form (James, 1980). The purposes of the present study were to assess the immediate and long-term effects of a moderate increase in complex carbohydrates to a level equivalent to the NACNE (1983) guidelines on (a) Fe and $\mathrm{Zn}$ balance, (b) absorptive efficiency of $\mathrm{Fe}$ and $\mathrm{Zn}$ by the use of stable isotopes and (c) $\mathrm{Fe}$ and $\mathrm{Zn}$ status. We also examined the effects on these indices of returning to the normal diet after prolonged ingestion of the diet containing the foods high in complex carbohydrates.

\section{EXPERIMENTAL}

\section{Experimental design}

Fifteen female volunteers participated in the study, which lasted for a total of 14 weeks, and was designed as shown in Table 1. In order to control the study effectively, subjects were split into two groups. Eight subjects participated from February to May 1986 and seven participated in exactly the same conditions and at the same time of year from February to May 1987.

During the week before the study, subjects weighed all food and drink consumed using Salter dietary scales weighing accurately to $5 \mathrm{~g}$, and recorded intakes in booklets provided. Each subject then ate a controlled diet of approximately the same energy and fibre content as their habitual diet, determined from previous $7 \mathrm{~d}$ weighed dietary records (see p. 600). The habitual diet, which will hereafter be called the normal-fibre (NF) diet, contained approximately $20 \mathrm{~g}$ fibre/d, calculated from standard food tables (Paul \& Southgate, 1978). The controlled NF diet was consumed from the first $6 \mathrm{~d}$ of the study (period 1) and duplicates of all food, faeces and urine corresponding to this period were collected.

At the end of the $6 \mathrm{~d}$ metabolic period, the volunteers consumed a diet containing increased amounts of complex carbohydrates in which higher-fibre foods were substituted for the lower-fibre foods of the NF diet. The higher-fibre (HF) diet was consumed for 12 weeks. During the first of these 12 weeks (the second week of the study), the subjects were given instructions and lists of HF foods to enable them to increase the fibre content of their diets by approximately $50 \%$ (from 20 to $30 \mathrm{~g} / \mathrm{d}$ ). This fibre increase mimics the long-term 
Table 1. Experimental design*

\begin{tabular}{|c|c|c|c|}
\hline $\begin{array}{l}\text { Week of study... } \\
\text { Days of study... } \\
\text { Metabolic study period... }\end{array}$ & $\begin{array}{l}1 \\
1-6 \\
1\end{array}$ & $\begin{array}{c}2 \\
7-14 \\
-\end{array}$ & $\begin{array}{c}3 \\
15-20 \\
2\end{array}$ \\
\hline \multirow[t]{2}{*}{ Diet... } & $\begin{array}{l}\text { Normal-fibre, } \\
\text { controlled }\end{array}$ & $\begin{array}{l}\text { High-fibre, } \\
\text { self-selected }\end{array}$ & $\begin{array}{l}\text { High-fibre, } \\
\text { controlled }\end{array}$ \\
\hline & $\begin{array}{l}\text { Collection of } \\
\text { food, faeces } \\
\text { and urine }\end{array}$ & - & $\begin{array}{l}\text { Collection of } \\
\text { food, faeces } \\
\text { and urine }\end{array}$ \\
\hline Blood sample on day... & 7 & - & 21 \\
\hline Stable isotope on day... & 2 & - & 16 \\
\hline Week of study... & 4-12 & 13 & 14 \\
\hline Days of study... & $21-84$ & $85-90$ & $91-96$ \\
\hline Metabolic study period... & - & 3 & 4 \\
\hline \multirow[t]{2}{*}{ Diet. } & $\begin{array}{l}\text { High-fibre, } \\
\text { self-selected }\end{array}$ & $\begin{array}{l}\text { High-fibre } \\
\text { controlled }\end{array}$ & $\begin{array}{c}\text { Normal-fibre, } \\
\text { controlled }\end{array}$ \\
\hline & - & $\begin{array}{l}\text { Collection of } \\
\text { food, faeces } \\
\text { and urine }\end{array}$ & $\begin{array}{l}\text { Collection of } \\
\text { food, faeces } \\
\text { and urine }\end{array}$ \\
\hline Blood sample on day... & - & 91 & 97 \\
\hline Stable isotope on day... & - & 86 & 92 \\
\hline
\end{tabular}

* A record of all food and drink consumed and gastrointestinal symptoms was made throughout the study.

NACNE (1983) recommendations. No instructions were given about intakes of other foods, the only objective being to increase intake of complex carbohydrates. Volunteers weighed and recorded all food and drink consumed during this week.

In week 3, subjects ate a controlled HF diet of approximately the same energy content as the NF diet in week 1 but with a $50 \%$ greater fibre content (approximately $30 \mathrm{~g} / \mathrm{d}$ ); the controlled HF diet was again consumed for $6 \mathrm{~d}$ (period 2) and all food, faeces and urine collected as described before.

From weeks 4 to 12, the subjects were again instructed to consume an HF diet, weighing and recording all food and drink as in week 2 and noting any gastrointestinal symptoms or other illness.

In week 13, the controlled HF diet was again consumed for $6 \mathrm{~d}$ (period 3). This was followed immediately by a $6 \mathrm{~d}$ period on the controlled NF diet (period 4) exactly the same as week 1. All food, faeces and urine corresponding to these two metabolic periods were collected as before.

One $20 \mathrm{ml}$ blood sample was collected on the morning after the last day of each of the four metabolic periods.

\section{Subjects}

These were fifteen females aged between 18 and 27 years (mean 22 (SEM 0.7) years). All were students from the Department of Nutrition at Kings's College Kensington, or technical staff from the Immunology Department at St Mary's Hospital, Paddington, London. Participation was voluntary and by fully informed and written consent. The subjects were healthy and without history of gastric dysfunction or anaemia. They were of normal bodyweight (mean 58.8 (SEM 1.6) $\mathrm{kg}$ ) for height (mean 1.66 (SEM 1) m) (Metropolitan Life Insurance Co., 1960) and body mass index (weight/height ${ }^{2}$, BMI) was within the normal range (mean 21.5 (SEM 0.5)). None were taking any regular medication or vitamin and 
mineral supplements and none had donated blood in the last 12 months. All subjects were omnivorous with habitual dietary fibre intakes of $15-25 \mathrm{~g} / \mathrm{d}$, assessed by $7 \mathrm{~d}$ weighed dietary records completed before recruitment into the study and calculated from standard food tables (Paul \& Southgate, 1978).

The subjects lived in either a hall of residence in the grounds of the college or in nearby accommodation and were encouraged to continue with their normal activities throughout the experiment. Their height and weights were recorded at the start of the study and they were thereafter weighed weekly. All remained healthy for the duration of the study, only one subject taking two $500 \mathrm{mg}$ paracetamol tablets to alleviate minor cold symptoms in the 8 th week.

\section{Diets}

Two separate menus were designed for the NF and the HF metabolic periods. The breakfasts were the same each day except for the second day when the Fe or $\mathrm{Zn}$ isotope was given in a cola drink instead of breakfast. The main meals were different each day. The increase in complex carbohydrates was achieved by substituting high-fibre muesli for cornflakes, wholemeal for white and brown bread, brown for white pasta, lentil for chicken soup, and consuming baked beans and extra potato.

Diets NF and HF contained approximately 6.3 MJ energy. Carbohydrate, protein and fat furnished approximately 47,17 and $36 \%$ of the total energy intake respectively. Dietary fibre calculated from standard food tables was $21 \mathrm{~g}$ in the NF diet and $33 \mathrm{~g}$ in the HF diet. The calculated macro- and micro-nutrient contents of the diets are shown in Table 2.

Energy intake was adjusted on the basis of the $7 \mathrm{~d}$ weighed records completed by the subjects before the start of the study by altering bread and margarine intake and offering sugar, biscuits and yoghurt.

In an attempt to ensure constancy of composition, as much food as possible was bought and main meals and sandwiches prepared before the start of the study. All the meals were prepared in the metabolic kitchen of the Nutrition Department and weighed to the nearest $0.1 \mathrm{~g}$. Single meals were transferred to plastic trays, wrapped in cling film and deep frozen. Only homogenized milk and fruit were bought weekly or as required.

On weekdays, the subjects ate their evening meals in the metabolic kitchen and took weighed and prepared food away for all weekend meals, breakfasts, lunches and snacks. They were instructed to eat all food provided and to eat no additional food. All tea, coffee and water consumed were weighed and recorded.

Two complete collections of the meals from diets NF and HF were made from each dietary period and homogenized using a Moulinex food processor. Duplicates of extra food consumed were collected and homogenized separately. Waste food was also weighed and homogenized. Measured amounts of deionized water were added where necessary to make the food into a paste. Portions were removed and freeze-dried and ground into a fine powder in a Moulinex coffee grinder for subsequent analysis.

\section{Isotope studies}

The eight subjects participating in 1986 were given the $\mathrm{Fe}$ isotope ${ }^{58} \mathrm{Fe}$ and the seven subjects participating in 1987 were given the $\mathrm{Zn}$ isotope ${ }^{68} \mathrm{Zn}$. Fe or $\mathrm{Zn}$ absorption was measured in each of the four study periods.

On the second day of each metabolic study period, the first eight subjects presented themselves after an overnight fast and were given $200 \mathrm{ml}$ of a cola drink containing $54 \mu \mathrm{mol}$ Fe as ferrous sulphate labelled with $20 \mu \mathrm{mol}{ }^{58} \mathrm{Fe}$ (AERE, Harwell), i.e. a total of $74 \mu \mathrm{mol}$ Fe. Two capsules, each containing 10 barium-impregnated radio-opaque pellets, were taken at the same time, in order to check for the completeness of the faecal collection. 
Table 2. Calculated nutrient composition $(/ d)$ of the normal-and high-fibre diets

\begin{tabular}{lcc}
\hline \hline & Normal-fibre & High-fibre \\
\hline Energy (MJ) & $6 \cdot 2$ & $6 \cdot 5$ \\
Protein (g) & 62 & 71 \\
Fat (g) & 58 & 62 \\
Carbohydrate (g) & 192 & 199 \\
Fibre (g) & 21 & 33 \\
Sodium (mmol) & 121 & 105 \\
Potassium (mmol) & 60 & 80 \\
Caleium (mmol) & 21 & 21 \\
Magnesium (mmol) & $10 \cdot 7$ & $15 \cdot 2$ \\
Phosphorus (mmol) & 36 & 42 \\
Iron $(\mu \mathrm{mol})$ & 198 & 248 \\
Copper $(\mu \mathrm{mol})$ & 19 & 25 \\
Zinc $(\mu \mathrm{mol})$ & 152 & 183 \\
Ascorbic acid (mg) & 112 & 120 \\
\hline
\end{tabular}

On the second day of each metabolic study period, the second seven subjects were given $200 \mathrm{ml}$ of a cola drink containing $138 \mu \mathrm{mol}{ }^{68} \mathrm{Zn}$ as zinc chloride (Technical and Optical Equipment, Edgware Rd, London), together with two capsules of radio-opaque pellets, as described above.

\section{Faecal and urine collection}

Faecal samples were collected using carmine BPC (250 mg in a capsule given before breakfast on the lst and 7 th days) to mark the beginning and end of the metabolic period. Intestinal transit times were measured with the carmine markers. Faecal samples were collected in large polyethylene bags and stored in plastic flasks. They were frozen as soon as possible, then weighed into foil trays, covered and stored at $-20^{\circ}$. Whole samples were freeze-dried, weighed and homogenized in a new Moulinex coffee grinder and pooled into 6-d lots. Samples were sieved through a plastic sieve and the number of radio-opaque pellets counted. The samples were thoroughly mixed in a powder mixer (Pascall Engineering, Crawley, Sussex) for $30 \mathrm{~min}$ and portions taken for analysis.

Urine samples $(24 \mathrm{~h})$ were collected into 2-litre plastic containers previously washed with dilute hydrochloric acid and containing $20 \mathrm{ml} 5 \mathrm{M}-\mathrm{HCl}$ (Analar grade) as preservative. The volume was measured, portions taken and stored at $-20^{\circ}$ before analysis.

\section{Serum collection}

On the morning after the last day of each metabolic study period, a $20 \mathrm{ml}$ venous blood sample was withdrawn from the antecubital vein of each subject into plastic syringes using stainless-steel needles. Blood was immediately transferred into plastic containers.

A $5 \mathrm{ml}$ sample of blood was reserved for the measurement of haemoglobin and packed cell volume (PCV). The remainder was centrifuged at $2000 \mathrm{~g}$ for $10 \mathrm{~min}$ and the serum separated using Pasteur pipettes. Serum was stored at $-20^{\circ}$ for subsequent analysis.

\section{Analytical procedures}

Fe and $\mathrm{Zn}$ concentrations in duplicate samples of food, faeces and urine were measured by atomic absorption spectroscopy (AAS; PU9000; Pye Unicam, Cambridge). Freeze-dried samples of food and faeces were ashed in silica crucibles in a muffle furnace for $48 \mathrm{~h}$ at $480^{\circ}$. When cool, $2 \cdot 5 \mathrm{ml}$ hot Analar concentrated $\mathrm{HCl}$ were added and the solution made up to $25 \mathrm{ml}$ with deionized water. The solutions were filtered through Whatman no. 542 filter 
Table 3. Total non-starch polysaccharide (NSP) contents of the diets $(\mathrm{g} / \mathrm{d})$

\begin{tabular}{lcccc}
\hline Diet & Cellulose & Soluble NCP & Insoluble NCP & Total NSP \\
\hline NF (period 1) & $3 \cdot 7$ & $10 \cdot 9$ & $4 \cdot 7$ & $19 \cdot 3$ \\
NF (period 4) & $3 \cdot 7$ & $10 \cdot 5$ & $4 \cdot 7$ & $18 \cdot 9$ \\
HF (period 2) & $5 \cdot 7$ & $12 \cdot 2$ & $11 \cdot 9$ & $29 \cdot 8$ \\
HF (period 3) & $6 \cdot 2$ & $13 \cdot 4$ & $10 \cdot 6$ & $30 \cdot 2$ \\
\hline
\end{tabular}

NCP, non-cellulosic polysaccharide; NF, normal-fibre diet on days 1-6 (period 1) and 91-96 (period 4); HF, high-fibre diet on days 15-20 (period 2) and 85-90 (period 3).

paper and stored in plastic vials at $4^{\circ}$. Urine samples were analysed by a wet ashing procedure with concentrated nitric acid. Reference standards were prepared from National Bureau of Standards wheat flour (SRM 1567) and analysed at the same time as the samples to verify accuracy. Coefficients of variation for control materials of $\mathrm{Fe}$ and $\mathrm{Zn}$ were $4 \cdot 1$ and $3.2 \%$ respectively. Duplicate portions of the faecal ash were analysed for ${ }^{58} \mathrm{Fe}$ by neutron activation analysis (NAA), as described previously (Fairweather-Tait et al. 1983) and for ${ }^{68} \mathrm{Zn}$ by fast atom bombardment mass spectroscopy (FABMS) using the same method as described for ${ }^{67} \mathrm{Zn}$ (Fairweather-Tait et al. 1989).

The phytate content of the basic diets was measured, separating the phytate by the method of Harland \& Oberleas (1986). Hydrolysis of phytate eluate was carried out with sulphuric acid for $3 \mathrm{~h}$ at $140^{\circ}$, and phosphorus analysis was by the method of Parker \& Peterson (1965).

The non-starch polysaccharide (NSP) content of diets NF and HF was measured in duplicate by the Englyst method (Englyst \& Cummings, 1984).

Serum ferritin was determined by radioimmunoassay (DuPont UK Ltd). Serum Zn was analysed by AAS. Haemoglobin was measured in whole blood by the cyanomethaemoglobin method (Cannan, 1958) and PCV by the microhaematocrit technique.

\section{Statistical analysis}

The values were analysed using the SAS statistical package. Two-way analysis of variance was used to test for significant differences. Where significant $F$ values were obtained, means were compared using the least significant difference (LSD) test (Montgomery, 1984). Initial and final serum and whole blood values were compared by the paired $t$ test. Statistical procedures were based on information in SAS User's Guide (Barr et al. 1976).

\section{Ethical considerations}

The experiment was approved by both King's College Human Experimentation Committee and the Ethical Committee of the AFRC Institute of Food Research, Norwich.

\section{RESULTS}

Phytate and NSP intakes

Phytate contents (mmol/d) of diets NF and HF were 0.3 and 0.6 respectively. Analysed NSP (g/d) contents are shown in Table 3 . NSP values were lower than dietary fibre values calculated from standard food tables.

\section{Marker recovery}

During each of the four study periods each subject received twenty radio-opaque pellets, given with the stable-isotope-labelled drink. Overall recovery was $96.5 \%$. 
Table 4. Faecal weights for fifteen women consuming normal- and high-fibre diets

(Means with their standard errors)

\begin{tabular}{|c|c|c|c|c|c|c|c|c|}
\hline \multirow[t]{2}{*}{ Diet... } & \multicolumn{2}{|c|}{ NF (period 1$)$} & \multicolumn{2}{|c|}{ HF (period 2) } & \multicolumn{2}{|c|}{ HF (period 3) } & \multicolumn{2}{|c|}{ NF (period 4) } \\
\hline & Mean & $\mathrm{SE}$ & Mean & $\mathrm{SE}$ & Mean & $\mathrm{SE}$ & Mean & $\mathrm{SE}$ \\
\hline Wet wt $(\mathrm{g} / \mathrm{d})$ & $111^{\mathrm{a}}$ & 8 & $158^{\mathrm{b}}$ & 13 & $127^{\mathrm{a}}$ & 15 & $126^{\mathrm{a}}$ & 10 \\
\hline Dry wt $(\mathrm{g} / \mathrm{d})$ & $35^{\mathrm{a}}$ & 2 & $45^{\mathrm{b}}$ & 3 & $39^{\mathrm{a}}$ & 3 & $35^{\mathrm{a}}$ & 2 \\
\hline Faecal water $(\mathrm{g} / \mathrm{kg})$ & $680^{\mathrm{a}}$ & 10 & $710^{\mathrm{a}}$ & 10 & $690^{\mathrm{a}}$ & 20 & $710^{\mathrm{a}}$ & 20 \\
\hline
\end{tabular}

${ }^{a}{ }^{D}$ Means in rows with different superscript letters were significantly different (least significant difference test): $P<0.05$.

NF, normal fibre diet on days 1-6 (period 1) and 91-96 (period 4); HF, high-fibre diet on days 15-20 (period 2) and $85-90($ period 3$)$.

Table 5. The effect of the high-fibre diet on haemoglobin $(H b)$, packed cell volume (PCV), serum ferritin and serum zinc

(Mean values with their standard errors)

\begin{tabular}{lccccc}
\hline & \multicolumn{2}{c}{ Initial } & & \multicolumn{2}{c}{ Final } \\
\cline { 2 - 3 } \cline { 5 - 6 } & Mean & SEM & & Mean & SEM \\
\hline Hb $(\mathrm{mg} / \mathrm{ml})$ & 129 & 2 & & 126 & 2 \\
PCV & 0.432 & 0.005 & & 0.431 & 0.005 \\
Serum ferritin $(\mu \mathrm{g} / \mathrm{l})$ & 36 & 5 & & 36 & 5 \\
Serum $\mathrm{Zn}(\mu \mathrm{mol} / \mathrm{l})$ & 15 & 1 & & 16 & 1 \\
\hline
\end{tabular}

\section{Body-weight and stool output}

Body-weights fluctuated throughout the 14-week study and five subjects each lost $1 \mathrm{~kg}$ but these changes were not significant. Mean faecal wet and dry weights (Table 4) both increased significantly with diet HF during period 2 but after 12 weeks decreased significantly compared with values obtained during period 2 . Although faecal weights were greater with diet $\mathrm{HF}$ in period 3 than with diet NF in period 1, this difference was not significant. On returning to diet NF (period 4), faecal wet weight did not decrease, but dry weight fell to the same level as in period 1. Mean transit time fell significantly $(P<0.05)$ from $50 \mathrm{~h}$ with diet NF (period 1) to $28 \mathrm{~h}$ with diet HF (period 2). Transit time with diet HF (period 3) was $32 \mathrm{~h}$ and with diet NF (period 4) was $30 \mathrm{~h}$. Transit time was significantly less in periods $2-4$ compared with period 1 .

\section{$\mathrm{Fe}$ and Zn status}

Mean values for haemoglobin, PCV, serum ferritin and serum $\mathrm{Zn}$ (Table 5) were in the normal range for women, although one subject had a low initial haemoglobin which increased after 12 weeks. Initial serum ferritins were $<20 \mu \mathrm{g} / \mathrm{l}$ in three subjects but increased to within the normal range in two of these subjects after 12 weeks on diet $\mathrm{HF}$. Results are shown only for diet NF (period 1) and diet HF (period 2) as there were no changes in the other periods. The diets apparently had no significant effects on these measurements.

\section{$\mathrm{Fe}$ and $\mathrm{Zn}$ balance}

There were no significant changes in $\mathrm{Fe}$ or $\mathrm{Zn}$ balance (Tables 6 and 7) nor in apparent absorption, although the inter-subject variation was large. In all but one subject apparent 
Table 6. Daily intake and excretion of iron ( $\mu \mathrm{mol})$ in eight subjects during the four dietary periods

Diet..

NF (period 1)

HF (period 2)

HF (period 3)

NF (period 4)

Subject

no.

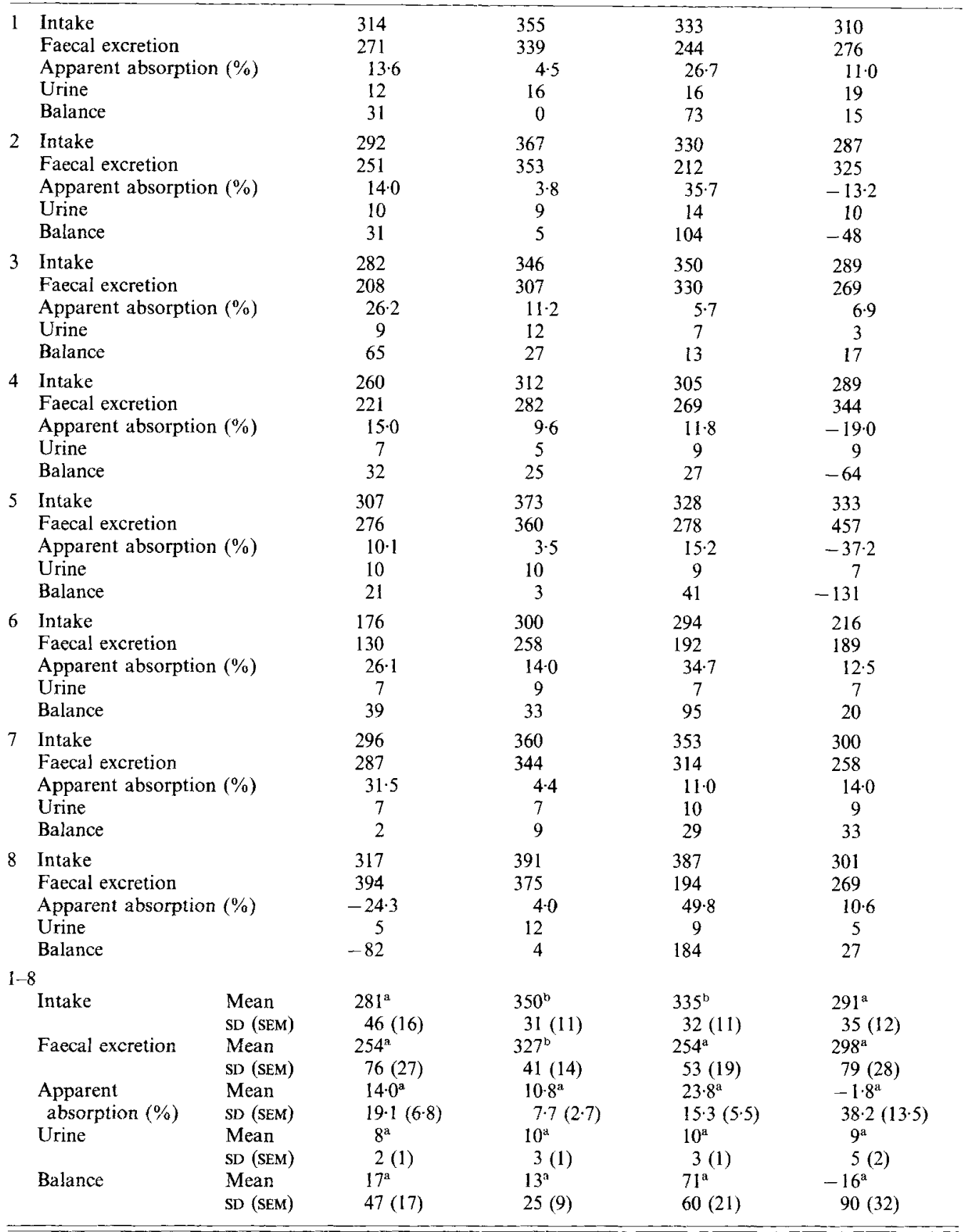

NF, normal-fibre diet on days 1-6 (period 1) and days 91-96 (period 4); HF, high-fibre diet on days 15-20 (period 2) and days 85-90 (period 3).

${ }^{a, b}$ Means in rows with different superscript letter were significantly different (least significant difference test): $P<0.05$. 
Table 7. Daily intake and excretion of zinc ( $\mu \mathrm{mol})$ in six subjects during the four dietary periods

\begin{tabular}{|c|c|c|c|c|c|c|}
\hline \multicolumn{3}{|c|}{$\begin{array}{l}\text { Diet... } \\
\text { Subject } \\
\text { no.* }\end{array}$} & NF (period 1) & HF (period 2) & HF (period 3) & NF (period 4) \\
\hline 9 & $\begin{array}{l}\text { Intake } \\
\text { Faecal excretion } \\
\text { Apparent absorp } \\
\text { Urine } \\
\text { Balance }\end{array}$ & $n(\%)$ & $\begin{array}{l}195 \\
129 \\
33 \cdot 9 \\
8 \\
58\end{array}$ & $\begin{array}{c}228 \\
221 \\
3 \cdot 0 \\
9 \\
-2\end{array}$ & $\begin{array}{c}230 \\
140 \\
39 \cdot 1 \\
8 \\
82\end{array}$ & $\begin{array}{c}191 \\
115 \\
39 \cdot 8 \\
9 \\
67\end{array}$ \\
\hline 10 & $\begin{array}{l}\text { Intake } \\
\text { Faecal excretion } \\
\text { Apparent absorp } \\
\text { Urine } \\
\text { Balance }\end{array}$ & $n(\%)$ & $\begin{array}{c}208 \\
195 \\
6 \cdot 3 \\
8 \\
5\end{array}$ & $\begin{array}{l}226 \\
160 \\
29 \cdot 2 \\
10 \\
56\end{array}$ & $\begin{array}{l}245 \\
260 \\
-6 \cdot 1 \\
8 \\
-23\end{array}$ & $\begin{array}{c}212 \\
220 \\
-3 \cdot 7 \\
9 \\
-17\end{array}$ \\
\hline 11 & $\begin{array}{l}\text { Intake } \\
\text { Faecal excretion } \\
\text { Apparent absorp } \\
\text { Urine } \\
\text { Balance }\end{array}$ & $n(\%)$ & $\begin{array}{c}190 \\
187 \\
1 \cdot 6 \\
8 \\
-5\end{array}$ & $\begin{array}{l}220 \\
187 \\
15 \cdot 0 \\
9 \\
24\end{array}$ & $\begin{array}{c}234 \\
223 \\
4 \cdot 7 \\
9 \\
2\end{array}$ & $\begin{array}{l}191 \\
150 \\
21 \cdot 5 \\
10 \\
31\end{array}$ \\
\hline 12 & $\begin{array}{l}\text { Intake } \\
\text { Faecal excretion } \\
\text { Apparent absorp } \\
\text { Urine } \\
\text { Balance }\end{array}$ & n $(\%)$ & $\begin{array}{l}195 \\
165 \\
15 \cdot 4 \\
10 \\
20\end{array}$ & $\begin{array}{l}221 \\
178 \\
19 \cdot 5 \\
9 \\
34\end{array}$ & $\begin{array}{l}209 \\
169 \\
19 \cdot 1 \\
12 \\
28\end{array}$ & $\begin{array}{c}189 \\
201 \\
-6.4 \\
6 \\
-18\end{array}$ \\
\hline 14 & $\begin{array}{l}\text { Intake } \\
\text { Faecal excretion } \\
\text { Apparent absorp } \\
\text { Urine } \\
\text { Balance }\end{array}$ & $(\%)$ & $\begin{array}{l}206 \\
172 \\
16 \cdot 5 \\
12 \\
22\end{array}$ & $\begin{array}{l}226 \\
198 \\
12 \cdot 4 \\
10 \\
18\end{array}$ & $\begin{array}{l}221 \\
180 \\
18 \cdot 6 \\
10 \\
31\end{array}$ & $\begin{array}{c}191 \\
229 \\
-19 \cdot 8 \\
9 \\
-47\end{array}$ \\
\hline 15 & $\begin{array}{l}\text { Intake } \\
\text { Faecal excretion } \\
\text { Apparent absorp } \\
\text { Urine } \\
\text { Balance }\end{array}$ & $(\%)$ & $\begin{array}{c}228 \\
250 \\
-9 \cdot 7 \\
8 \\
-30\end{array}$ & $\begin{array}{c}246 \\
343 \\
-39 \cdot 4 \\
10 \\
-107\end{array}$ & $\begin{array}{c}251 \\
249 \\
0 \cdot 8 \\
14 \\
-12\end{array}$ & $\begin{array}{l}222 \\
138 \\
37 \cdot 8 \\
10 \\
74\end{array}$ \\
\hline \multicolumn{7}{|c|}{$9-15$} \\
\hline & Intake & $\begin{array}{l}\text { Mean } \\
\text { SD (SEM) }\end{array}$ & $\begin{array}{l}204^{\mathrm{a}} \\
14(6)\end{array}$ & $\begin{array}{l}227^{\mathrm{b}} \\
48(18)\end{array}$ & $\begin{array}{l}232^{b} \\
15(6)\end{array}$ & $\begin{array}{l}199^{a} \\
14(6)\end{array}$ \\
\hline & Faecal excretion & $\begin{array}{l}\text { Mean } \\
\text { SD (SEM) }\end{array}$ & $\begin{array}{l}183^{a} \\
40(16)\end{array}$ & $\begin{array}{l}213^{\mathrm{a}} \\
66(27)\end{array}$ & $\begin{array}{l}203^{\mathrm{a}} \\
48(20)\end{array}$ & $\begin{array}{l}176^{\mathrm{a}} \\
47(19)\end{array}$ \\
\hline & $\begin{array}{l}\text { Apparent } \\
\text { absorption }(\%)\end{array}$ & $\begin{array}{l}\text { Mean } \\
\text { SD (SEM) }\end{array}$ & $\begin{array}{l}10 \cdot 6^{\mathrm{a}} \\
14 \cdot 9(6 \cdot 1)\end{array}$ & $\begin{array}{c}6 \cdot 6^{a} \\
24 \cdot 1(9 \cdot 8)\end{array}$ & $\begin{array}{l}12 \cdot 7^{2} \\
16 \cdot 3(6 \cdot 7)\end{array}$ & $\begin{array}{l}11 \cdot 5^{\mathrm{a}} \\
25 \cdot 0(10 \cdot 2)\end{array}$ \\
\hline & Urine & $\begin{array}{l}\text { Mean } \\
\text { SD (SEM) }\end{array}$ & $\begin{array}{l}9^{a} \\
2(1)\end{array}$ & $\begin{array}{l}10^{4} \\
2(1)\end{array}$ & $\begin{array}{l}11^{\mathrm{a}} \\
4(1)\end{array}$ & $\begin{array}{l}9^{a} \\
1(1)\end{array}$ \\
\hline & Balance & $\begin{array}{l}\text { Mean } \\
\text { SD (SEM) }\end{array}$ & $\begin{array}{l}12^{\mathrm{a}} \\
30(12)\end{array}$ & $57(23)$ & $\begin{array}{l}18^{n} \\
38(16)\end{array}$ & $\begin{array}{l}15^{\mathrm{a}} \\
50(20)\end{array}$ \\
\hline
\end{tabular}

NF, normal-fibre diet on days 1-6 (period 1) and days 91-96 (period 4); HF, high-fibre diet on days 15-20 (period 2) and days $85-90$ (period 3).

a,b Means in rows with different superscript letter were significantly different (least significant difference test): $P<0.05$.

* Subject no. 13 had faecal $\mathrm{Zn}$ losses of $>400 \mu \mathrm{mol} / \mathrm{d}$ and was excluded. 
Fe absorption decreased with diet HF in period 2 and increased with diet HF in period 3. Apparent Fe absorption decreased in six subjects on returning to diet NF in period 4 . The subjects as a whole were in positive Fe balance throughout the study except after returning to the NF diet, when Fe balance became slightly negative. All subjects were in positive $\mathrm{Fe}$ balance on diet HF during periods 2 and 3 .

$\mathrm{Zn}$ balance in the whole group was maintained throughout the study. Mean $\mathrm{Zn}$ balance and apparent absorption fell with diet HF in period 2, but increased with diet HF in period 3 ; these changes were not significant.

Dietary intakes of $\mathrm{Fe}$ and $\mathrm{Zn}$ increased significantly on diet $\mathrm{HF}$. Fe excretion increased significantly with diet $\mathrm{HF}$ in period 2 and decreased with diet HF in period 3. Zn excretion also increased with diet $H F$ in period 2 and fell with diet $H F$ in period 3 , but these differences were not significant.

\section{Absorptive efficiency of $\mathrm{Fe}$ and $\mathrm{Zn}$}

The isotope values are shown in Figs. 1 and 2. There were no significant changes in the apparent absorption of either ${ }^{58} \mathrm{Fe}$ or ${ }^{68} \mathrm{Zn}$ at each time studied, although there was much inter-subject variation. Mean percentage absorption from the four consecutive test meals was 32.7 (SEM 10.2), 31.5 (SEM 6.6), 33.5 (SEM 7.5) and 43.5 (SEM 5.4) for ${ }^{58} \mathrm{Fe}$, and 50.6 (SEM 5.4), $49 \cdot 7$ (SEM 3.9), 38.1 (SEM 5.2) and 50.4 (SEM 8.3) for ${ }^{68} \mathrm{Zn}$. It is interesting to note that on returning to diet NF at the end of the study, seven out of eight subjects showed increased $\mathrm{Fe}$ absorption and five out of seven subjects showed increased absorption of $\mathrm{Zn}$.

\section{DISCUSSION}

The aim of the present study was to effect only a moderate increase in the complex carbohydrate content of the diet (following NACNE (1983) recommendations) by the use of conventional foods rather than unphysiological amounts of fibre isolates. There has been much enthusiasm for these recommendations and it is encouraging that a moderate increase in complex carbohydrates showed no overall deleterious effects on $\mathrm{Fe}$ and $\mathrm{Zn}$ balance and, more importantly, on $\mathrm{Fe}$ and $\mathrm{Zn}$ status.

High-fibre diets have been recommended in slimming regimens, e.g. the F-plan diet (Eyton, 1982), but usually in conjunction with energy restriction. The subjects in the present study maintained body-weight throughout the 14 week period, and although the diet contained more fibre there was no attempt to restrict energy intake. All the subjects were very conscientious, only one subject admitting to an extra bar of chocolate during period 1, analysis of which was included in the intake values. Most of the subjects enjoyed their diets and found their fibre target during the 12-week self-selection period relatively easy to achieve.

Analysed NSP contents of diets NF and HF were lower than calculated dietary fibre values. This is mainly because the Englyst \& Cummings (1984) method for NSP does not include values for resistant starch and lignin, which are included in fibre values in standard food tables.

Complex carbohydrates are an important determinant of faecal output and a $50 \%$ increase in fibre intake increased faecal weight by $42 \%$ in period 2 . Increase in faecal weight was not so great as in some studies (Judd, 1982; Andersson et al. 1983), but the intake of complex carbohydrates was lower. Cereals (often as bran or wholemeal bread) are often more effective at increasing faecal weight than fruits and vegetables (Stasse-Wolthuis $e t$ al. 1980; Stephen \& Cummings, 1980). In the present study, mixed diets were given and increase in complex carbohydrate intake was achieved by use of cereals and fruit and vegetables. The observation that much of the increase in complex carbohydrate intake 


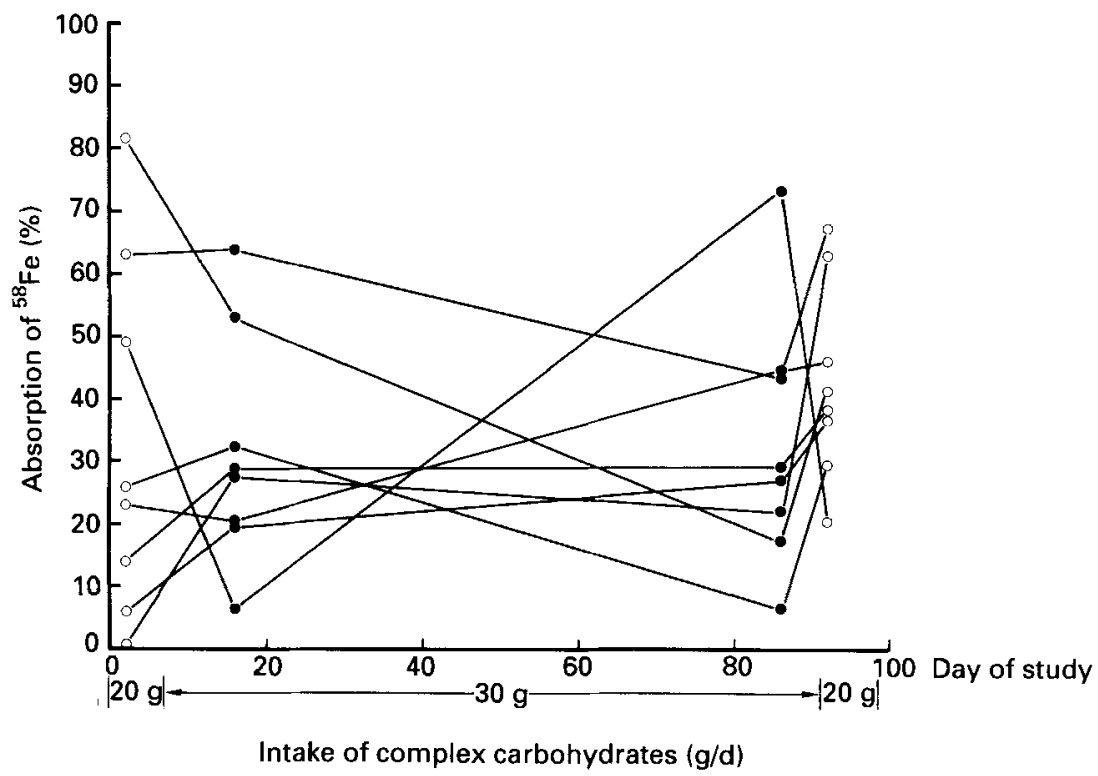

Fig. 1. The effect of a moderate increase in intake of complex carbohydrates on iron absorption in eight adult women from $54 \mu \mathrm{mol} \mathrm{Fe}$ as ferrous sulphate labelled with $20 \mu \mathrm{mol}{ }^{58} \mathrm{Fe}$ (as ferric chloride).

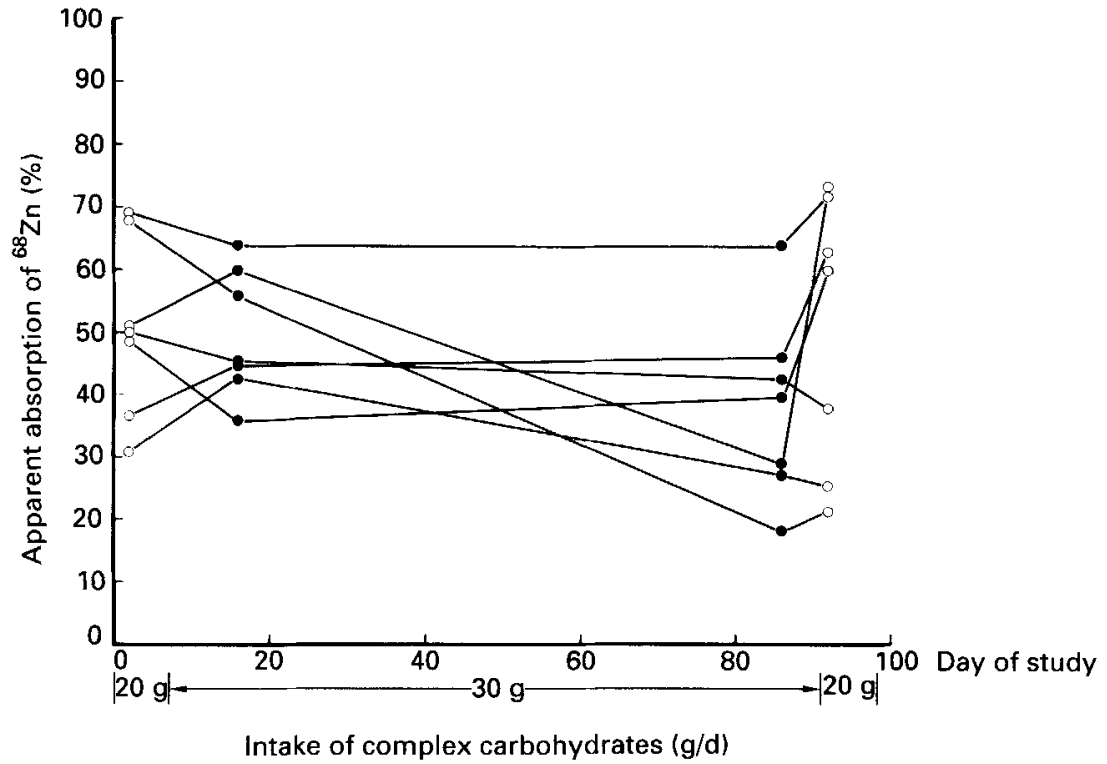

Fig. 2. The effect of a moderate increase in intake of complex carbohydrates on apparent zinc absorption in seven adult women from $138 \mu \mathrm{mol}{ }^{68} \mathrm{Zn}$ as zinc chloride.

during the HF diet periods was in the insoluble NCP fraction (Table 3) would indicate that cereal fibre predominated.

The decrease in faecal weight in period 3 is probably part of an adaptive response. The mixed fibre source would provide a readily usable substrate for the stimulation of colonic 
microbial growth in the initial weeks of the study, with the increase in bacterial mass contributing to the increased faecal output in period 2 (Stephen \& Cummings, 1980). There is some evidence for stabilization of bacterial mass and stool weight in rats after 4 weeks of fibre consumption (Walter et al. 1986). Stool weights also stabilized in man after 7 weeks of bran consumption (Beck et al. 1986) and fell slightly after 4 weeks of cellulose or pectin consumption (Spiller et al. 1980). We did not measure either the bacterial mass or the complex carbohydrate content of the faeces, so we cannot comment on any microbial change or alteration in fibre digestibility that there might have been over the 12 week HF diet period. However, there was a fall in wet and dry faecal weight in period 3, so it is possible that after an initial increase, colonic bacterial mass had stabilized as part of an adaptive response to the prolonged feeding of complex carbohydrates, contributing to the decrease in faecal weight.

The decrease in faecal dry weight in period 4 was probably the result of the lower intake of complex carbohydrates. Total faecal weight did not fall during this period, possibly in part because there was no immediate decrease in microbial mass, as reported in other studies. For example, Robertson et al. (1979) found that stool weight did not fall until 3 weeks after carrot consumption was discontinued. The habitual diet was only consumed for $6 \mathrm{~d}$ after the end of the HF diet period and this is obviously not a long enough period for transit times and faecal weights to fall to the values obtained at the start of the study.

There was little change in percentage water content of the faeces during the 12 week period, but water content seems to be fairly tightly controlled (Eastwood et al. 1980). Mean stool moisture values were low, with water contents of $<700 \mathrm{~g} / \mathrm{kg}$ in six subjects throughout the study, but women have been shown to produce harder stools than men (Davies et al. 1986). In premenopausal women, stool weight is sometimes affected by the different phases of the menstrual cycle. Davies et al. (1986) have shown that there is a significantly greater proportion of soft stools produced during the menstrual phase of the cycle and that stool weights are greater at this time than in the luteal phase. This may be related to release of prostaglandins at this stage of the menstrual cycle (Rees \& Rhodes, 1976). In the present study, it is interesting that faecal weights actually increased in eight subjects in period 4 when intake of complex carbohydrates decreased. Menstruation dates were noted and five of these subjects started to menstruate during this experimental period.

The Fe and $\mathrm{Zn}$ excretion values fall in the range reported by Hallfrisch et al. (1987) and Spiller et al. (1986). Both balance and isotope studies showed a wide inter-subject variation in $\mathrm{Fe}$ and $\mathrm{Zn}$ absorption, although the variation was somewhat less with $\mathrm{Zn}$. Large differences between subjects in Fe absorption have been shown previously (FairweatherTait \& Minski, 1986), and this makes it difficult to determine to what extent differences in absorption are related to change in diet or to the Fe status of the subject. Fe status has often been regarded as a major determinant of non-haem-Fe absorption (Rossander et al. 1979). Serum ferritin levels are considered to be a good indication of body Fe stores, but in the present study there was no correlation between ferritin concentrations and ${ }^{58} \mathrm{Fe}$ absorption. Differences in $\mathrm{Fe}$ absorption cannot, therefore, be explained in terms of differences in $\mathrm{Fe}$ status.

It has been suggested that the short-term control of Fe absorption is mediated through the mucosal cells of the small intestine (Fairweather-Tait \& Wright, 1984) and that this mechanism is independent of whole-body status. Previous results (Fairweather-Tait \& Wright, 1984, Fairweather-Tait et al. 1985, Fairweather-Tait \& Minski, 1986) show that Fe absorption is inversely and exponentially related to the previous day's Fe intake. There was a weak inverse correlation between previous day's Fe intake and ${ }^{58} \mathrm{Fe}$ absorption $(r-0 \cdot 3$, $P<0.05$ ), so this may partly explain the differences in Fe absorption. The effect of previous $\mathrm{Fe}$ intake on $\mathrm{Fe}$ absorption seems to be diminished as the time interval increases 
(Fairweather-Tait et al. 1985). There was no correlation in the present study between ${ }^{58} \mathrm{Fe}$ absorption and the previous week's Fe intake, so although Fe intake was controlled only in the week before period 4, this does not explain the wide variation in Fe absorption.

Results of most human studies show that complex carbohydrates do not have a great effect on Fe balance (Kelsay, 1981), although bran but not pectin or cellulose was shown to decrease Fe absorption (Cook et al. 1983). There was a significant increase in faecal $\mathrm{Fe}$ excretion during period 2, but apparent absorption and balance did not change significantly due to the increase in Fe intake. There was a non-significant improvement in Fe balance during period 3 , but the isotope study showed almost no change in the absorptive capacity of the intestine for Fe. Fe excretion increased during period 4 and balance became slightly negative, but this could be due to the incomplete collection of the previous week's Fe intake.

$\mathrm{Zn}$ absorption was not correlated with the previous day's or previous week's Zn intake. There was also no correlation between serum $\mathrm{Zn}$ and absorption of ${ }^{68} \mathrm{Zn}$, but serum $\mathrm{Zn}$ is probably not a very sensitive indicator of $\mathrm{Zn}$ status.

There is some evidence that complex carbohydrates decrease $\mathrm{Zn}$ balance (Kelsay, 1981), but it is possible that the body can adapt to diets low in $\mathrm{Zn}$ or diets of poor $\mathrm{Zn}$ availability (Campbell et al. 1976). Apparent absorption and $\mathrm{Zn}$ balance decreased during period 2 and increased again in period 3 , but these changes were not significant.

Phytate content of the diet appears to influence $\mathrm{Zn}$ availability. While phytate intake approximately doubled on diet HF, this difference was not so marked as in other studies. Daily intakes of phytate in non-vegetarian menus were $0.4 \mathrm{mmol}$ but in vegetarian menus were $3.9 \mathrm{mmol}$ (Oberleas \& Harland, 1981). The greatest concentration of phytate is found in legume seeds, bran and germ of cereal grains, with only small amounts in fruit and vegetables. However, we did not give large quantities of bran, wheat germ, nuts or beans, therefore we achieved only a relatively modest increase in phytate intake. It has been suggested that the phytate: $\mathrm{Zn}$ molar ratio is a predictor of $\mathrm{Zn}$ availability, whereby ratios of less than 10 are thought to be acceptable in providing adequate dietary $\mathrm{Zn}$, and daily ratios consistently above 20 may jeopardize $\mathrm{Zn}$ status (Oberleas \& Harland, 1981). Phytate: $\mathrm{Zn}$ ratios were 2.5 on diet NF and 3.5 on diet $\mathrm{HF}$, so it is not surprising that no deleterious effects were seen on $\mathrm{Zn}$ absorption.

Although the isotope results very broadly agree with the results of the balance study, that is, no significant effect of fibre on $\mathrm{Fe}$ and $\mathrm{Zn}$ absorption, it is interesting to note that individual results very often do not follow the same pattern with regard to mineral absorption from a single dose of isotope and apparent absorption from the diet, measured over a $6 \mathrm{~d}$ period. The fact that there were no changes in haemoglobin, PCV, serum ferritin or serum $\mathrm{Zn}$ confirms the lack of effect of a moderate increase in complex carbohydrates on mineral nutrition. These results agree with those of an earlier study in which the effects of 'fibre filler', a mixture of cereals, fruit and nuts given as part of the F-plan diet (Eyton, 1982) on $\mathrm{Fe}$ and $\mathrm{Zn}$ status were monitored in adults for 12 weeks (Fairweather-Tait et al. 1988). The addition of fibre-filler ( $12 \mathrm{~g}$ NSP) to the daily diet did not have an adverse effect on $\mathrm{Zn}$ status, in subjects not undergoing a weight-reducing regimen.

The present study has demonstrated the acceptability of an increase in complex carbohydrate intake in a small group of young females, in line with recent recommendations. While there was much individual variation in $\mathrm{Fe}$ and $\mathrm{Zn}$ absorption, overall balances and absorptions did not change significantly. A moderate increase in complex carbohydrate intake using commonly consumed foods had no deleterious effects on the bioavailability of Fe and $\mathrm{Zn}$. There appeared to be a tendency towards improvement in both Fe and $\mathrm{Zn}$ balance after 12 weeks on the HF diet. However, results of the isotope study suggested that this could not be explained in terms of an increased efficiency of 
absorption of $\mathrm{Fe}$ or $\mathrm{Zn}$, and the fact that there were no measurable changes in $\mathrm{Fe}$ and $\mathrm{Zn}$ status suggests that the differences in the balance results were of no great biological significance.

The authors thank Mr A. J. A. Wright for the phytate analysis, Dr H. Englyst for the dietary fibre analysis and $\mathrm{Mr}$ David Lincoln for the ferritin assays.

\section{REFERENCES}

Anderson, B. M., Gibson, R. \& Sabry, J. H. (1981). The iron and zinc status of long-term vegetarian women. American Journal of Clinical Nutrition 34, 1042-1048.

Andersson, H., Navert, B., Bingham, S. A., Englyst, H. N. \& Cummings, J. H. (1983). The effects of breads containing similar amounts of phytate but different amounts of wheat bran on calcium, zinc and iron balance in man. British Journal of Nutrition 50, 503-510.

Barr, A. J., Goading, J. H., Sall, J. P. \& Helwig, J. T. (1976). A User's Guide to SAS 76. Raliegh, NC: Spark Press.

Beck, B., Villaume, C., Bau, H. M., Gariot, P., Chayvialle, J. A., Desalme, A. \& Debry, G. (1986). Long-term influence of a wheat-bran supplemented diet on secretion of gastrointestinal hormones and on nutrient absorption in healthy man. Human Nutrition: Clinical Nutrition 40C, 25-33.

Campbell, B. J., Reinhold, J. G., Cannell, J. J. \& Nourmand, I. (1976). The effects of prolonged consumption of wholemeal bread upon metabolism of calcium, magnesium, zinc and phosphorus of two young American adults. Pahlavi Medical Journal 7, 1-17.

Cannan, R. K. (1958). Proposal for a certified standard for use in haemoglobinometry. Clinical Chemistry 4 , 246-251.

Cook, J. D., Noble, N. L., Morck, T. A., Lynch, S. R. \& Petersburg, S. J. (1983). Effect of fiber on nonheme iron absorption. Gastroenterology 85, 1354-1358.

Davies, G. J., Crowder, M., Reid, B. \& Dickerson, J. W. T. (1986). Bowel function measurements of individuals with different eating patterns. Gut 27, 164-169.

Department of Health and Social Security (1984). Diet and Cardiovascular Disease. Report on Health and Social Subjects no. 28. London: H.M. Stationery Office.

Eastwood, M. A., Brydon, W. G. \& Tadesse, K. (1980). Effect of fiber on colon function. In Medical Aspects of Dietary Fiber, pp. 1-26 [G. A. Spiller and R. M. Kay, editors]. New York: Plenum Medical Book Co.

Englyst, H. \& Cummings, J. (1984). Simplified method for the measurement of total non-starch polysaccharides by gas-liquid chromatography of constituent sugars as alditol acetates. Analyst 109, 937-942.

Eyton, A. (1982). F-plan Diet. Harmondsworth, Middlesex: Penguin Books Ltd.

Fairweather-Tait, S. J. \& Minski, M. J. (1986). Studies on iron availability in man, using stable isotope techniques. British Journal of Nutrition 55, 279-285.

Fairweather-Tait, S. J., Minski, M. J. \& Richardson, D. P. (1983). Iron absorption from a malted cocoa drink fortified with ferric orthophosphate using the stable isotope ${ }^{58} \mathrm{Fe}$ as an extrinsic label. British Journal of Nutrition 50, 51-60.

Fairweather-Tait, S. J., Piper, Z., Hurren, C. A. \& Fox, T. E. (1988). Studies on the consumption of "fibre-filler" for twelve weeks in humans: effects on iron status and plasma zinc. Journal of Human Nutrition and Dietetics 1, 337-346.

Fairweather-Tait, S. J., Portwood, D. E., Symss, L. L., Eagles, J. \& Minski, M. J. (1989). Iron and zinc absorption in human subjects from a mixed meal of extruded and non-extruded wheat bran and flour. American Journal of Clinical Nutrition 49, 151-155.

Fairweather-Tait, S. J., Swindell, T. E. \& Wright, A. J. A. (1985). Further studies in rats on the influence of previous iron intake on the estimation of bioavailability of Fe. British Journal of Nutrition 54, 79-86.

Fairweather-Tait, S. J. \& Wright, A. J. A. (1984). The influence of previous iron intake on the estimation of bioavailability of Fe from a test meal given to rats. British Journal of Nutrition 51, 185-191.

Hallberg, L., Rossander, L. \& Skanberg, A.-B. (1987). Phytates and the inhibitory effect of bran on iron absorption in man. American Journal of Clinical Nutrition 45, 988-996.

Hallfrisch, J., Powell, A., Carafelli, C., Reiser, S. \& Prather, E. S. (1987). Mineral balances of men and women consuming high fiber diets with complex or simple carbohydrate. Journal of Nutrition 117, 48-55.

Harland, B.F. \& Oberleas, D. (1986). Anion-exchange method for determination of phytate in foods: collaborative study. Journal of the Association of Official Analytical Chemists 69, 667-670.

Hegsted, D. M., Moscosco, I. \& Collazos, C. (1952). A study of the minimum calcium requirements of adult men. Journal of Nutrition 46, 181--187.

James, W. P. T. (1980). Dietary fiber and mineral absorption. In Medical Aspects of Dietary Fibre, pp. 239-259 [G. A. Spiller and R. M. Kay, editors]. New York: Plenum Medical Book Co.

Judd, P. A. (1982). The effect of high intakes of barley on gastrointestinal function and apparent digestibilities of dry matter, nitrogen and fat in human volunteers. Journal of Plant Foods 4, 79-88. 
Kelsay, J. L. (1981). Effect of dietary fiber level on bowel function and trace mineral balances of human subjects. Cereal Chemistry 58, 2-5.

Malm, O. J. (1958). Calcium requirements and adaptation in adult men. Scandinavian Journal of Clinical and Laboratory Investigation 10, Suppl. 36, 108-199.

Metropolitan Life Insurance Co. (1960). Statutory Bulletin 41, 6.

Montgomery, D. C. (1984). Design and Analysis of Experiments. New York: John Wiley \& Sons.

National Advisory Committee on Nutrition Education (1983). Proposals for Nutritional Guidelines for Health Education in Britain. London: Health Education Council.

Oberleas, D. \& Harland, B. F. (1981). Phytate content of foods: effect on dietary zinc bioavailability. Journal of the American Dietetic Association 79, 433-436.

Parker, F. \& Peterson, N. F. (1965). Quantitative analysis of phospholipids and phospholipid fatty acids from silica gel thin layer chromatography. Journal of Lipid Research 6, 455-460.

Paul, A. A. \& Southgate, D. A. T. (1978). Mc Cance and Widdowson's The Composition of Foods, 4th revised and extended ed, MRC Special Report no. 297. London: H.M. Stationery Office.

Pilch, S. M. [editor] (1987). Physiological Effects and Health Consequences of Dietary Fiber. Bethesda, MD: Life Sciences Research Office, Federation of American Societies for Experimental Biology.

Rattan, J., Levin, N., Graff, E., Weizer, N. \& Gilat, T. (1981). A high-fiber diet does not cause mineral and nutrient deficiencies. Journal of Clinical Gastroenterology 3, 389-393.

Rees, W. D. W. \& Rhodes, J. (1976). Altered bowel habit and menstruation. Lancet ii, 475.

Robertson, J., Brydon, W. G., Tadesse, K., Wenham, P., Walls, A. \& Eastwood, M. A. (1979). The effect of raw carrot on serum lipids and colon function. American Journal of Clinical Nutrition 32, $1889-1892$.

Rossander, L., Hallberg, L. \& Bjorn-Rasmussen, E. (1979). Absorption of iron from breakfast meals. American Journal of Clinical Nutrition 32, 24842489.

Southgate, D. A. T. \& Englyst, H. N. (1985). Dietary fibre: chemistry, physical properties and analysis. In Dietary Fibre, Fibse Depleted Foods, and Disease, pp. 31-35 [H. Trowell, D. Burkitt and K. W. Heaton, editors]. London: Academic Press.

Spiller, G. A., Chernoff, M. C., Hill, R. A., Gates, J. E., Nassar, J. J. \& Shipley, E. A. (1980). Effect of purified cellulose, pectin, and a low-residue diet on fecal volatile fatty acids, transit time, and fecal weight in humans American Journal of Clinical Nutrition 33, 754-759.

Spiller, G. A., Story, J. A., Wong, L. G., Nunes, J. D., Alton, M., Petro M. S., Furumonto, E. J., Whittam, J. H. \& Scala, J. (1986). Effect of increasing levels of hard wheat fiber on fecal weight, minerals and steroids and gastro-intestinal transit time in healthy young women. Journal of Nutrition 116, 778-785.

Stasse-Wolthuis, M., Albers, H. F. F., Van Jeveren, J. G. C., Wil de Jong, J., Hautvast, J. G. A. J., Hermus, R. J. J., Katan, M. B., Brydon, W. G. \& Eastwood, M. A. (1980). Influence of dietary fiber from vegetables and fruits, bran or citrus pectin on serum lipids, fecal lipids, and colonic function. American Journal of Clinical Nutrition 33, 1745-1756.

Stephen, A. M. \& Cummings, J. H. (1980). Mechanism of action of dietary fibre in the human colon. Nature 284, 283-284.

Walker, A. R. P. (1987). Dietary fibre and mineral metabolism. Molecular Aspects of Medicine 9, 69-87.

Walker, A. R. P., Fox, F. W. \& Irving, J. T. (1948). Studies in human mineral metabolism. 1. The effect of bread rich in phytate phosphorus on the metabolism of certain mineral salts with special reference to calcium. Biochemical Journal 42, 452-462.

Walter, D. J., Eastwood, M. A., Brydon, W. G. \& Elton, R. A. (1986). An experimental design to study colonic fibre fermentation in the rat: the duration of feeding. British Journal of Nutrition 55, 465-479. 